\title{
Neurochemical phenotype and birthdating of specific cell populations in the chick retina
}

\author{
KARIN DA COSTA CALAZA ${ }^{1}$ and PATRICIA F. GARDINO ${ }^{2}$ \\ ${ }^{1}$ Departamento de Neurobiologia, Instituto de Biologia, Programa de Pós-Graduação em Neurociências \\ Universidade Federal Fluminense, Av. Outeiro São João Batista, s/n, 24020-140 Niterói, RJ, Brasil \\ ${ }^{2}$ Laboratório de Neurobiologia da Retina, Instituto de Biofísica Carlos Chagas Filho \\ Programa de Pós-Graduação em Ciências Biológicas (Biofísica), Universidade Federal do Rio de Janeiro \\ Av. Carlos Chagas Filho 373, bloco C, sala C1-031, 21941-902 Rio de Janeiro, RJ, Brasil \\ Manuscript received on March 18, 2009; accepted for publication on November 16, 2009
}

\begin{abstract}
The chick embryo is one of the most traditional models in developing neuroscience and its visual system has been one of the most exhaustively studied. The retina has been used as a model for studying the development of the nervous system. Here, we describe the morphological features that characterize each stage of the retina development and studies of the neurogenesis period of some specific neurochemical subpopulations of retinal cells by using a combination of immunohistochemistry and autoradiography of tritiated-thymidine. It could be concluded that the proliferation period of dopaminergic, GABAergic, cholinoceptive and GABAceptive cells does not follow a common rule of the neurogenesis. In addition, some specific neurochemical cell groups can have a restrict proliferation period when compared to the total cell population.
\end{abstract}

Key words: developing, neurogenesis, neurotransmitter systems, ontogenesis, proliferation.

\section{INTRODUCTION}

Cells in the chick retina are generated during specific periods in a regulated profile, and some cell populations overlap the periods of their neurogenesis, as occurs in other species (Marquardt and Gruss 2002, Martins and Pearson 2008). The chick retina has been widely used as a model for studying the development of the nervous system, particularly because: (a) it is a tissue where the access is simplified by the fact that it is located out of the neuro axis, although it is part of the central nervous system; (b) it has a pattern of synaptic organization and a development similar to other central structures; (c) it shows a highly ordered histological organization; (d) it has almost all, if not all, neurotransmitters found in the brain; (e) pre- and post-synaptic components of

Correspondence to: Karin da Costa Calaza

E-mail: karin@vm.uff.br the neurotransmitter circuitries are present in the tissue. Since the diversity of neurotransmitters is extremely high, and as the beginning of the expression of the machinery responsible for the synthesis, release and recognition of many neurotransmitters is not synchronous, different neurochemical phenotypes may be generated during the same proliferating periods or only during a restricted developmental interval. Thus, it is very important to associate the histogenesis of this tissue with the neurogenesis of specific cellular types.

\section{NeURochemiCAL DIVERSITY OF CELL TYPES \\ IN THE CHICK RETINA}

With transmitter uptake studies, immunohistochemistry or cytotoxic lesions, almost all known neurotransmitters and neuromodulators have been demonstrated to be present in the vertebrate retina (Ehrlich and Morgan 1980, Kiyama et al. 1985, Spira et al. 1987, Tung et 
al. 1990). In particular, the heterogeneous population of amacrine cells employs a wide spectrum of synaptic transduction modulators, including substance $\mathrm{P}$, dopamine, enkephalin, vasoactive intestinal polypeptide, adenosine, glucagon, somatostatin, serotonin, avian pancreatic polypeptide, acetylcholine, neurotensin, neuropeptide Y, corticotrophin releasing factor, glutamate and GABA (Kiyama et al. 1985, Fukuda et al. 1981, Spira et al. 1987, Hokoç et al. 1990, Paes de Carvalho and de Mello 1982, de Carvalho et al. 1992, Gardino et al. 1993, Kalloniatis and Fletcher 1993, Thoreson and Witkovsky 1999, Sun and Crossland 2000).

The retina has two basic circuitries for light analysis: one formed by photoreceptors, bipolar and ganglion cells that represent the vertical pathway, and the other formed by horizontal and amacrine cells, called lateral pathway, which modulates the vertical pathway of visual information. At a glance, the retina seems to have simplified circuitries because of the small number of neuronal types composing the tissue (only five in the chick retinal tissue: photoreceptors, horizontal, bipolar, amacrine and ganglion cells) and one main glial type: Müller cells. However, it is not that simple. In general, morphological, electrophysiological and neurochemical parameters are used to classify the many cell subtypes of the retina. Each cell type subdivides into subtypes that make specific connections to other specific cells contributing to different functions of the retina. Even in the chick, both types of photoreceptors (cones and rods) are necessarily functional in different light conditions. There are at least four distinct subtypes of horizontal cells, and it has been suggested that there may be more than thirty different types of amacrine cells (Fischer et al. 1998b, 1999, 2005, 2006, 2007, Masland 2001, 2004).

\section{Histogenesis OF THE CHICK RETINA}

The eyes arise from the posterior part of the forebrain, the diencephalon, while the optic tecta derive from the dorsal portion of the midbrain. An invagination of the primary optic vesicle leads to a bilaminated structure, the eye cup or the secondary optic vesicle. The neural retina derives from the thickened inner layer of this primordial eye, while the outer layer, in contact with aggregating mesenchyme that will later form the sclera and the choroid coat, also gives rise to the retinal pigmented epithelium (RPE). At the beginning of retinal development all cells are multipotent (Hyer et al. 1998), and even embryonic day 4.5 (E4.5) epithelial cells can be induced to transdifferentiate into neural phenotypes (Coulombre and Coulombre 1965).

Proliferation of RPE ceases early while stem cells continue to divide in the presumptive neural retina. The basic patterns of mitosis, vertical cellular migration and differentiation resemble the processes found throughout the early neural tube (Mey and Thanos 2000). The pattern of mitotic activity and, consequently, the maturation of the retina, follow a central to peripheral and temporal to nasal gradient (Rager et al. 1993).

After the report of the embryological origin of the neural retina, morphological features that characterize each embryonic stage established by Hamburger and Hamilton (1951; referred as $\mathrm{H}-\mathrm{H})$ will be revised as follow.

\section{EMBRYONIC DAY 3-5 (E5 = H-H STAGE 25)}

Around E3 or E4, the prospective neural retina becomes invaginated and located apposed onto the future RPE appearing as a two-layered optic cup. The pigmentation of the eye begins after E3 (Hamburger and Hamilton 1951). At E4 or E5, Müller fibers are present in the fundic region and Müller endfeet begin to form the internal limiting membrane (Coulombre 1955). The cellular strata of the retina derive from several radial migrations and the cessation of these neuroblast movements at various levels. The structural differentiation is evident beginning on $\mathrm{E} 4$ when the prospective retinal ganglion cells (RGCs) round up, increase in size, and begin to send out the axons that will form the optic fiber layer (OFL). At E5, the tissue shows a ventricular zone and a neuroblastic layer (NBL) (Fig. 1A-B). The former, near the future RPE, contains mainly proliferating cells, and the latter contains cells with elongated shape that, after their final mitosis (in the ventricular zone), migrate towards the vitreal side and differentiate into neurons or glial cells. In the innermost neuroblastic layer (iNBL), many round shaped cells can be visualized near the vitreal side, mainly formed by RGCs. Newborn horizontal cells migrate bi-directionally from their site of birth, close to the ventricular side, to the adjacent (vitreal) side of the neuroepithelium. At this point, they 
align just next to the prospective ganglion cell layer before migrating back again to their final laminar position in the external part of the future inner nuclear layer. The bi-directional migration occurs between Hamburger and Hamilton stages 24 and 33, which are equivalent to embryonic days 4.5 and 8 (Edqvist and Hallböök 2004).

Finally, in this period, a very high density of apoptotic nuclei appears in the neuroepithelium of the central retina representing the cell death related to early proliferative retinal stages (Chavarría et al. 2007).

\section{EMBRYONIC DAY 6-7 (H-H STAGES 29-31)}

Because of the intense early proliferation of ganglion cells cited above, at E6 the ganglion cell layer (GCL) is constituted of two or three rows of cell bodies (Fig. 1CD) extending over most central retina (Coulombre 1955). A clear segregation of retinal strata begins at about E6 with the appearance of the GCL, OFL and NBL (Spence and Robson 1989, Meller and Tetzlaff 1976). The first axonal process from RGC begins to arrive at the optic tectum at E6 (Delong and Coulombre 1965, LaVail and Cowan 1971). In this period, it has been described a low incidence of cell death in both NBL and RGC (Chavarría et al. 2007).

\section{EMBRYONIC DAY 8 (H-H STAGE 34)}

At E8, very distinguishable from early retinas, the inner plexiform layer (IPL) appears in the central region of the retina (Fig. 2A) even though the GCL still appears with three rows of cell bodies. Furthermore, Müller fibers and the outer limiting membrane are found throughout the neural retina as can be observed with $2 \mathrm{M} 6$, a glial marker specific for chick retina (Schlosshauer et al. 1991) (Fig. 2B-C). The two plexiform layers of the mature retina result from neurite growth and dendritic branching that takes place during all the embryonic life.

\section{EMBRYONIC DAY 9-10 (H-H STAGES 35-36)}

The retina of animals on the $9^{\text {th }}$ day of incubation is very typical because the outer plexiform layer (OPL) makes its appearance (Fig. 2D-E). Besides that, between E9 (Fig. 2D-E) and E10 (Fig. 2F-G), displaced amacrine cells occupy a transitory intraplexiform position in the IPL, forming a discontinuous one-cell-thick layer (Fig. 2D-G; Génis-Gálvez et al. 1977). These authors sug- gested that the unusual position of the displaced amacrine cells in the IPL could be related to a growth in the thickness of the IPL between the displaced amacrine and the ganglion cells during the $9^{\text {th }}$ and $10^{\text {th }}$ days of incubation. This would lead to their appearance in an intraplexiform position. Then, the ulterior rapid elongation of a cytoplasmic stalk between the bushy arborization and the soma explains the apparent disappearance of those cells in that intraplexiform position, and the displaced amacrine cells become mixed with the ganglion cells. Thus, as we can see in Figure 2 (D-E), on the $9^{\text {th }}$ day of incubation, the cell bodies are in the center of the IPL and, on the $10^{\text {th }}$ day, the nucleus adopts a position nearer the GCL (Fig. 2F-G). Finally, it is not before E9 that photoreceptor neuroblasts show a round shaped apical process beyond the outer limiting membrane into the subretinal space (Fig. 2D-E), and the extension of inner segments of photoreceptors is the first indication of their morphogenesis (Olson 1979, Meller 1984 apud Mey and Thanos 2000).

At E10-E11, the number of ganglion cell axons is estimated at 4 million, but $40 \%$ of them will be eliminated up to E18 and, then, remain constant (Rager and Rager 1978). Probably because of the peak of cell death period, at E9, GCL does not appear with three rows of cell bodies anymore (Fig. 2E; Cook et al. 1998, Chavarría et al. 2007).

\section{EMBRYONIC DAY 11-13 (H-H STAGES 37-39)}

Comparing two different ages, at E10 and E13 (Figs. $2 \mathrm{~F}-\mathrm{G}$ and $3 \mathrm{~A}$ ), the IPL increases in thickness and it will continue to grow, presumably up to adult life (Fig. 4). In addition, displaced amacrine cells are not in an intraplexiform position anymore, and are present in the GCL after E12 or E13 (Hamburger and Hamilton 1951). Concerning the programmed cell death, the density of TUNEL-positive nuclei shows a new increase affecting in the inner nuclear layer (INL) with a peak at E11 (Chavarría et al. 2007). At E12, all axonal processes from RGC reached the optic tectum. Soon after, at E13, the GCL contains mainly one row of cells (Fig. 3A-B) due to cell death, as mentioned above. At the same day, on E13, the first functional synapses are observed in the IPL (Hughes and LaVelle 1974, Hering and Kröger 1996). Photoreceptors mature late in the retinal devel- 


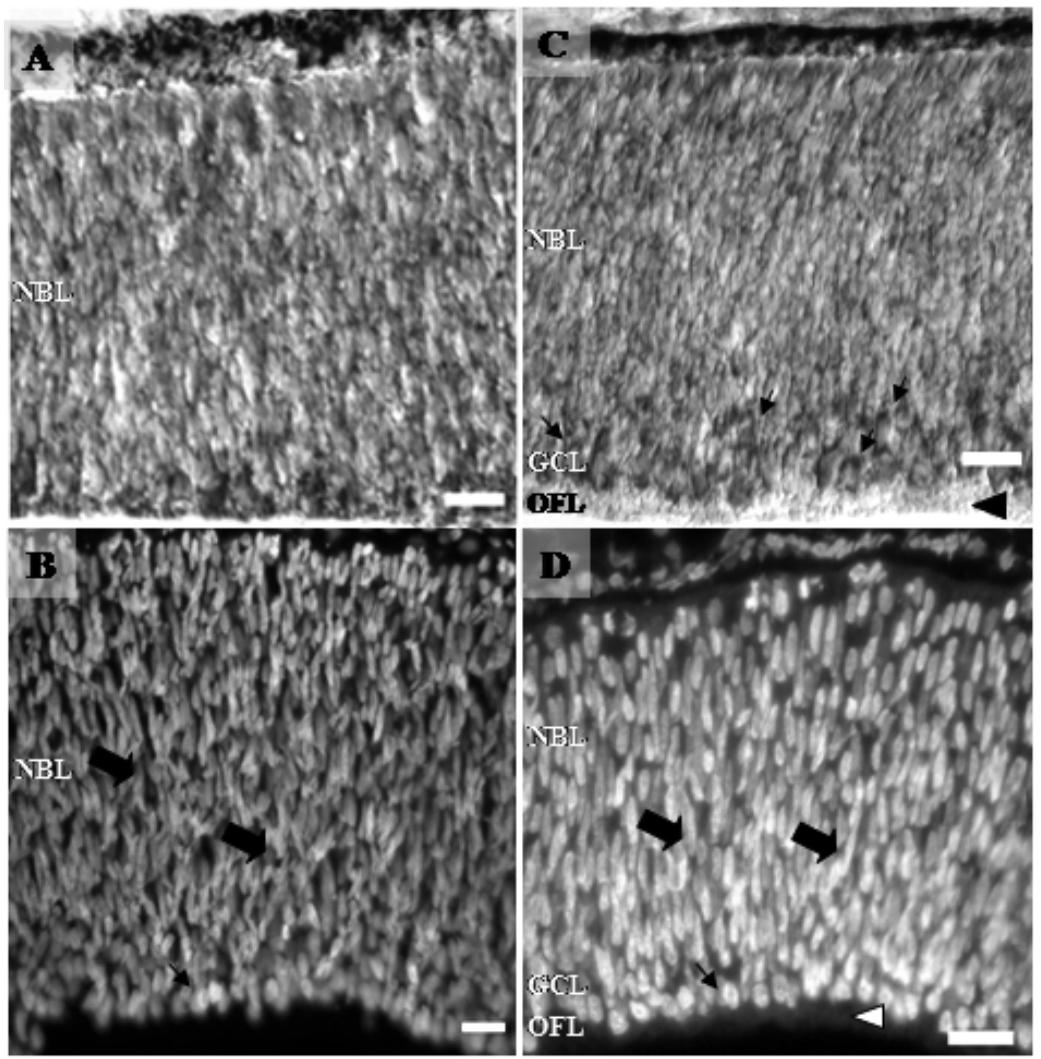

Fig. 1 - Photomicrographs of retinal sections from E5 (A and B) and E6 (C and D). Retinal sections stained for cresyl violet (A and C) and DAPI (B and D). In C, arrows point to round shaped cells of the future ganglion cell layer (GCL), and black arrowhead shows the optic fiber layer (OFL) region. In $\mathrm{B}$ and $\mathrm{D}$, elongated (thick arrows) and round shaped nucleus (thin arrows) in separate layers; neuroblastic (NBL) and presumptive ganglion cell layer (GCL) can be visualized. In D, white arrowhead points to the OFL. Calibration bars $=20 \mu \mathrm{m}$.

opment. The first receptor potentials are detected only after E13, and with the progress of the embryonic age, their increasing amplitude could be correlated with the appearance of photoreceptor outer segments that begin on the $15^{\text {th }}$ day (Meller and Tetzlaff 1976, Hanawa et al. 1976).

\section{EMBRYONIC DAY 14-16 (STAGE H-H 40-42)}

Around E14, horizontal cells undergo some morphological changes and, from one of their main dendrites, a single axon arises of these cells. With Golgi silver impregnation, synaptic spines can be distinguished 2 days later on dendrites and axon terminals (Génis-Galvéz et al. 1981). In parallel, oligodendrocyte precursors are observed in the retina around E14 and one day later oligodendrocyte processes multiply and begin to envelop thicker axons. However, as at E18, only $3 \%$ of the axons of the optic nerve are ensheathed, and most of the myelination takes place during the early postnatal period (Rager 1976).

It is on the $15^{\text {th }}$ day that rod and cone outer segments appear (Fig. 3C, white arrow), and both photoreceptor types begin a very rapid increase in length. Although the extension of RGCs spine-like process to the IPL begins after E7, the morphological development of these cells is completed around E16. From this age, the retina tissue would only increase in complexity and thickness.

\section{LATE DEVELOPMENT TO POST-HATCH}

The chicken retina contains one type of rods and four types of cones, each characterized by an opsin with different spectral absorbance: rhodopsin and red-, green-, blue-, and violet-cone opsin (Araki et al. 1990, Okano et al. 1992). In Figure 4(A), in post-hatched retinas, it is possible to see the outer and inner segments of photore- 


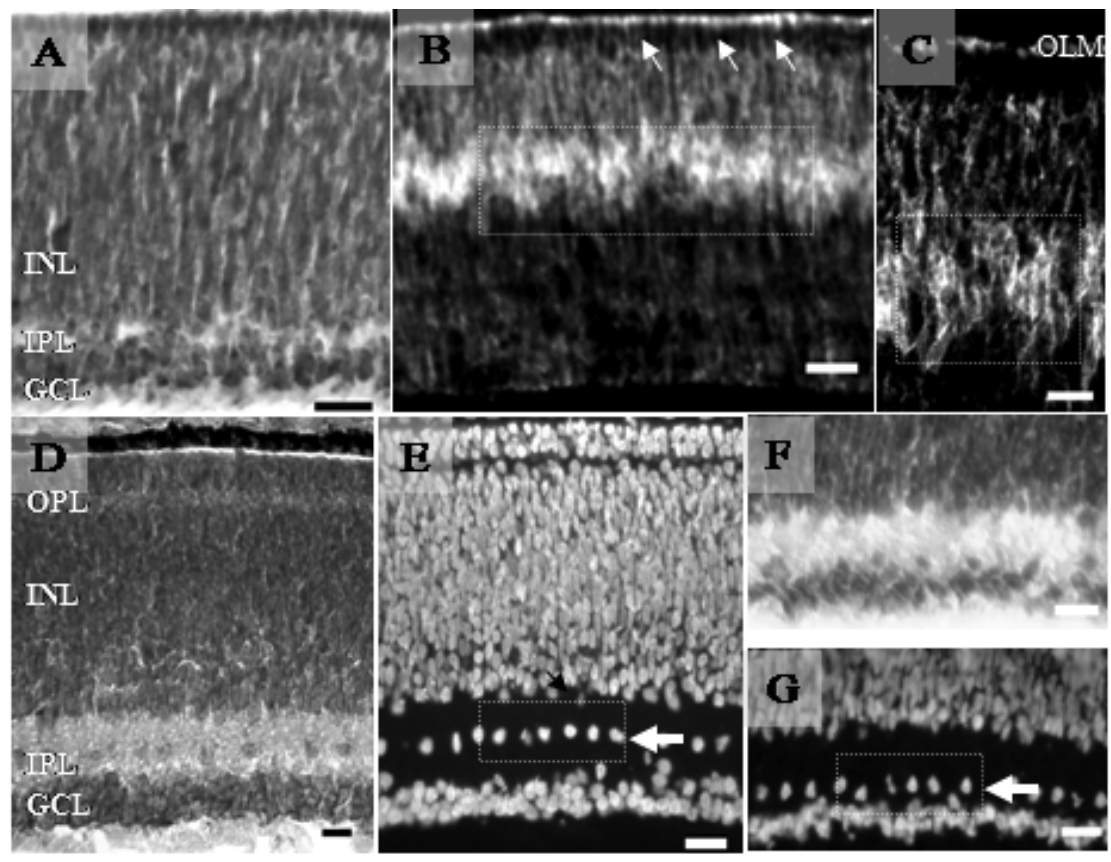

Fig. 2 - Photomicrographs of retinal sections from E8-E10 animals. In A, retinal section from E8 stained for cresyl violet (A) and immunoreactivity to 2M6, a specific Müller cell marker of the chick retina (B and C). In A, a clear segregation between the GCL and the inner nuclear layer (INL) is observed by the presence of the presumptive inner plexiform layer (IPL). In B and C, white arrows point to Müller cells endfeet, and soma cells take the middle region of INL (white rectangle). At E9 (D and E) and E10 (F and G), retinal sections stained for cresyl violet (D and F) and DAPI (E and G). At E9, the future outer plexiform layer (OPL) is present, turning the retina into a three nuclear layer tissue. The displaced amacrine cells in the characteristic intraplexiform position in the IPL, forming a discontinuous one-cell-thick layer in both ages (E9 and E10, white rectangles and arrows). Note the difference of displaced amacrine cells position in E9 and E10. OLM, outer limiting membrane. Calibration bars $=20 \mu \mathrm{m}$.

ceptors. The chick retina has a specialized area (Ehrlich 1981), called area centralis, functionally similar to the primate fovea with the highest visual acuity enriched in red and green cones and no rods (Cepko 1996). During the development, red and green opsins are expressed first (E14), then rhodopsin follows (E15), and finally the blue and violet opsins (E16) (Bruhn and Cepko 1996). The development of rod and cone photoreceptors is similar, although rod outer segments are formed earlier. First, synapses between bipolar cells and photoreceptors are not observed in the OPL before E17 (Hughes and LaVelle 1974, Meller 1984 apud Mey and Thanos 2000). In accordance to that, the normal electrical response to light stimulation develops between E17 and P3 (Hanawa et al. 1976). In fact, the electroretinogram shows a mature profile only at E19. At that time, 2 days before hatching, light evokes beak clapping and movements of the eyelids (Oppenheim 1968, Rager 1979 apud Mey and Thanos 2000). Concerning to the cell death, none TUNEL-positive nuclei are seen in the GCL and INL at E16 and E18, respectively (Chavarría et al. 2007).

Finally, in post-hatched retinas, the outer limiting membrane (OLM) (Fig. 4A, thick arrow) and some cells in the middle of IPL, called intraplexiform cells (Fig. 4B-C), can also be visualized.

\section{NEUROGENESIS OF RETINAL CELLS}

As discussed above, retinal neuroblasts leave the cell cycle in a specific order with respect to their prospective cell type: the first to be generated are retinal ganglion cells, followed by photoreceptors, then amacrine cells, horizontal cells and bipolar cells, which are the last neurons to leave the cell cycle in the chick retina. The production of photoreceptors continues over a longer period (Prada et al. 1991, Fekete et al. 1994, Meller 1984 apud Mey and Thanos 2000). Those specific sequences of cell proliferation are quite conserved in several vertebrate species (Marquardt and Gruss 2002, Martins and 

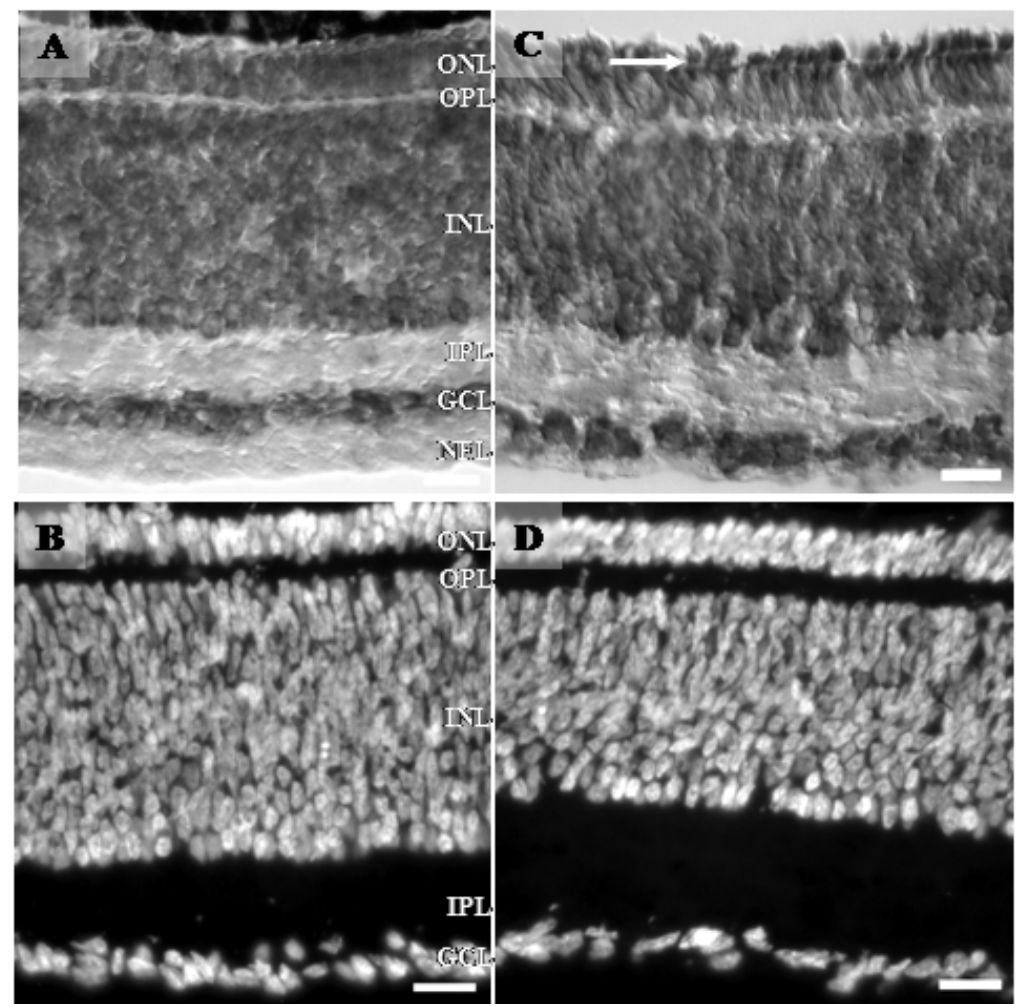

Fig. 3 - Photomicrographs of retinal sections from E13 (A and B) and E15 (C and D) stained for cresyl violet (A and C) and DAPI (B and D). In $\mathrm{C}$, an arrow points to the outer segments of photoreceptors. Note the round shaped cells in the innermost regions of the INL and the growing of the plexiform layers. GCL is almost constituted by a one cell row (C and D). Calibration bars $=20 \mu \mathrm{m}$.
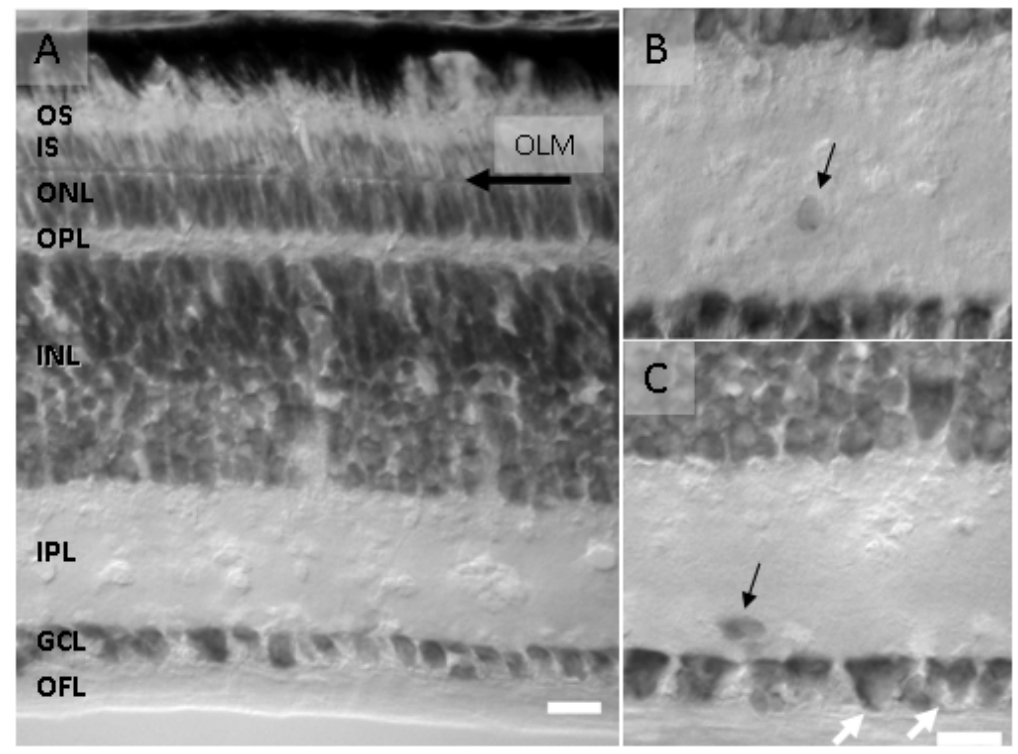

Fig. 4 - Photomicrographs of retinal sections of post-hatched animals stained for cresyl violet. In A, all retinal layers are clearly visualized, including the inner and outer segments segregation. An arrow points to the OLM as a line separating the ONL and the photoreceptors segments. In B and C, rounded cells (arrows) rarely observed in the middle of the IPL, called intraplexiform cells. GCL is constituted by a one cell row with cells of different sizes (white arrows). Calibration bars $=20 \mu \mathrm{m}$. 
Pearson 2008). In addition, the neurogenesis sequence occurs in a stereotypical order, but shows a strong overlap (Kahn 1973, Spence and Robson 1989, Prada et al. 1991). However, a question remains to be clarified: would there be a specific temporal order for neurogenesis of different neurochemical subpopulations of a specific cell type in the chick retina? Efforts to answer this question have been made through studies involving the neurogenesis of dopaminergic, GABAergic, cholinoceptive and GABAceptive cells using the association of immunohistochemical and autoradiography of tritiated thymidine techniques in the chick retina. The main methodology to evaluate neurogenesis is the cumulative approach, developed by Fujita and Horii (1963). Originally, it was described with the use of [3H]-thymidine as a tracer. Nowadays, this problem can also be approached with the use of BrdU (Farah 2004). Either 3H-thymidine or BrdU have to be applied for a prolonged period to label all the cells that go through S-phase after tracer administration. So, for neurogenesis in avian retina, the tracer is injected once in ovo on different embryonic days (E1E11), and the tissue is dissected at the end of the incubation period (around E19) when the retina is considered to be morphologically mature and the programmed cell death is finished. After that, retinas are analyzed for the presence of the tracer, and two populations are found: labeled cells (those that passed through S-phase while the tracer was available) and unlabeled cells (those that completed their terminal S-phase before the initiation of the cumulative labeling).

\section{BIRTH DATING SPECIFIC RETINAL CELLS}

Several reports have addressed the neurogenesis period of specific neurochemical subpopulations of retinal cells (Gardino et al. 1993, 1996, da Costa Calaza et al. 2000, Barros et al. 2003) by using a combination of immunohistochemistry and the cumulative method (Fujita and Horii 1963). As the [3H]-thymidine injected in ovo remains available to be incorporated into the DNA for several days, immunolabeled cells without [3H]-thymidine, i.e. without autoradiographical silver grains, are judged to have been generated prior the time of $[3 \mathrm{H}]-$ thymidine injection. On the other hand, double-labeled cells (immunolabeled cells showing autoradiographical silver grains) are considered to be in mitotic division and, therefore, are judged to have not been generated at the time of the $[3 \mathrm{H}]$-thymidine injection.

\section{DOPAMINERGIC AMACRINE CELLS}

The most abundant cathecolamine in the chick retina, as in some other species, is dopamine (Ehinger 1978). The retinal dopaminergic amacrine cells, visualized by the expression of the enzyme tyrosine hydroxylase, show a shorter neurogenesis period, between E3 and E7 (Gardino et al. 1993). According to the literature, the generation of amacrine cells begins at E3 and is concluded at E9 (Fujita and Horii 1963, Kahn 1974, Prada et al. 1991). In rat retina, Evans and Battelle (1987) have reported that the dopaminergic amacrine cells are generated during embryonic ages 16-20, whereas the first detection of TH was reported at post-natal day 3 (PN3), it means several days after the end of neurogenesis period. However, Wu and Cepko (1993), by using a modified staining method, have detected TH immunoreactive cells in retinal whole-mount preparations at embryonic day 19. Therefore, in rats, it seems that $\mathrm{TH}$ detection is almost simultaneously to the dopaminergic cell neurogenesis period. On the other hand, in the avian retina, it has been demonstrated that TH expression is indeed delayed in 4-5 days in relation to the end of the proliferation period (Gardino et al. 1993). In addition, these authors demonstrated that the specific dopaminergic amacrine cell subpopulation displays a more restrict neurogenesis period than the general amacrine cell population (Fig. 5). Similarly, TH-immunoreactive cells appear late during the development of the cat retina (Mitrofanis et al. 1988) and at the end of neurogenesis of the total amacrine cell population in this species (Robinson 1988). This delay could reflect the existence of a narrow window during the development when undifferentiated dopaminergic cells are capable of being influenced by specific signals. It is well known that the activity of cathecolaminergic enzymes is regulated by hormonal and neural inputs, but the mechanism that underlies the induction of TH expression is only now beginning to be solved. Signals conveyed by cAMP are important to determine the $\mathrm{TH}$ phenotype (Guimarães et al. 2001). More recently, Borba et al. (2005) have shown that PACAP is an important endogenous peptide influencing the definition of the tyrosine hydroxy- 
lase phenotype of retinal dopaminergic cells within this narrow window of development. Finally, the neurogenesis period of dopaminergic cells in the chick retina ends when the width of the IPL rapidly increases (Coulombre 1955), and the TH immunoreactive cells are first detected after amacrine migration to their final position (Prada et al. 1987). In addition, the first detection of TH positive cells is temporally coincident with some of the above cited events of the chick retina development, for example the beginning of synaptogenesis in the IPL and the maximum activation of dopamine-dependent adenylyl cyclase activity (Ventura et al. 1984). Nevertheless, the factors responsible for dopaminergic specific cell proliferation remain unsolved.

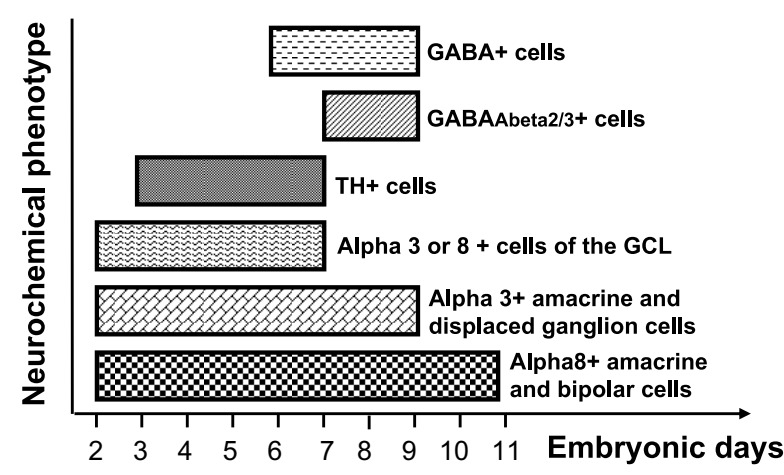

Fig. 5-Schematic histogram of neurogenesis periods of different neurochemical cell subpopulations Note that subpopulations of amacrine cells, for example, expressing different phenotypes, can have different neurogenesis periods (compare alpha8 + amacrine cells and TH+ cells).

\section{Cholinoceptive CELLS}

The chick retina contains a prominent cholinergic system, which includes three populations of cholinergic amacrine cells that could be identified by the expression of choline acetyltransferase (ChAT), the enzyme responsible for the synthesis of acethylcoline (ACh) (Millar et al. 1985, Spira et al. 1987). Both ChAT and acetylcholinesterase (AchE), the enzyme that metabolizes ACh, are found very early in the developing tissue and are also present in the mature retina (Shen et al. 1956, Spira et al. 1987). These cholinergic markers are found in amacrine cells in the INL (cholinergic cell type I and III) and in displaced amacrine in the GCL (cholinergic cell type II) since E6.5 (ChAT) and E4.5 (AChE). Other aspects of the cholinergic system, such as mod- ulation of choline acetyltransferase activity and regulation of vesicular acetylcholine transporter (Loureirodos-Santos et al. 2001, 2002, Prado et al. 2002), have also been studied.

Concerning cholinoceptive aspects, nicotinic and muscarinic acetylcholine receptors are expressed in the chick retina (Vogel and Nirenberg 1976, Large et al. 1985, Hamassaki-Britto et al. 1994, Fischer et al. 1998a, da Costa Calaza et al. 2000). Muscarinic acetylcholine receptors modulate cell cycle and calcium signaling in the chick retinal ventricular zone (Pearson et al. 2002, Syed et al. 2004). Acting through nicotinic acetylcholine receptors, ACh seems to play important roles in neurite outgrowth of ganglion cells, dendritic filopodia motility and remodeling during synaptogenesis, and development of spontaneous rhythmic activity in retinal ganglion cells during the period in which their connectivity pattern is shaped (Wong et al. 1998, Wong and Wong 2001). Therefore, the neurogenesis pattern of the cholinergic system is an important parameter considered to establish the temporal relationship between histogenesis and definition of functional phenotypes.

Alpha 3 subunit nicotinic receptors are observed in amacrines, displaced ganglion cells, and cells in the ganglion cell layer. Alpha 8 subunits are seen in amacrine and bipolar cells, as well as in cells in the ganglion cell layer (Hamassaki-Britto et al. 1994). The first cells that exhibit either alpha 3 or alpha 8 immunolabeling are almost certainly presumptive ganglion cells. Thereafter, the expression of both subunits are seen in amacrine neurons, followed by alpha 8 subunit in bipolar cells and alpha 3 in displaced ganglion cells in the inner nuclear layer. These results reveal not only different developmental patterns of cells containing alpha 3 and alpha $8 \mathrm{nAChR}$ subunits, but also indicate that both subunits are expressed in the chick retina before ChAT and well before retinal synaptogenesis (Araki et al. 1982). In addition, despite the fact that nAChRs alpha 3 and alpha 8 subunits have different time courses of development in the embryonic chick retina, it could also be suggested that the birth of cholinoceptive cells followed the neurogenesis time course of specific cell types.

From neurogenesis studies, it was established that the alpha 3-positive neurons in the ganglion cell layer leave the cell cycle from E2 through E7 (Gardino et 
al. 1996). Alpha 3-immunoreactive cells in the INL (amacrine and displaced ganglion cells) leave the cell cycle from E2 through E9. The alpha 8-positive cells in the ganglion cell layer are born between E1 and E7, and those in the inner nuclear layer (amacrine and bipolar cells) from E2 through E11. At least one difference was noticed between the neurogenesis of alpha 3- and alpha 8-positive neurons in the chick retina (Fig. 5). The cells in the ganglion cell layer that stained for alpha 3 begin to leave the cell cycle almost one day later than the alpha 8-positive neurons do. Furthermore, until E4, the alpha 3-positive cells were observed to leave the cell cycle at a slower rate than the one of alpha 8-positive cells. However, the expression of the alpha 3 subunit begins almost one day before (Hamassaki-Britto et al. 1994). These results suggest that the factors controlling the expression of alpha 3 and alpha $8 \mathrm{nAChR}$ subunits in the chick retina appear to be relatively independent of those that control cell genesis. Indeed, the ontogenesis of alpha 3 and alpha 8 nAChR subunits in the chick retina is not related in any simple way to the neurogenesis of neurons bearing those receptor subunits. The neurogenesis rates of alpha 3- and alpha 8-positive amacrine cells also appear to differ slightly, although in this case no difference in their ontogenesis has been noticed in a previous study (Hamassaki-Britto et al. 1994). Finally, previously reported data suggest that the time of birth of cholinoceptive neurons in the chick retina follows the general pattern of cell generation in this tissue (Gardino et al. 1996).

\section{GABAERGIC AND GABACEPTIVE CELls}

L-Glutamate (L-Glu) and $\gamma$-aminobutyric acid (GABA) are widely recognized as mediators of excitatory and inhibitory neurotransmissions, respectively, in the central nervous system, including the retina of many vertebrate species (Mosinger et al. 1986, Yazulla 1986, Massey and Redburn 1987, Thoreson and Witkovsky 1999). The GABAergic system is composed of a large population of cells, mainly constituted of amacrine neurons, with many important functions in the development and physiology of the retina (Catsicas and Mobbs 2001, Barnstable 1993, Ge et al. 2007, Luján et al. 2005, Sernagor et al. 2003, Tachibana and Kaneko 1988, Yazulla 1986). In fact, GABA is visualized in horizontal and amacrine cells and in cells in the GCL, most of them containing glutamate, probably used as a precursor for GABA synthesis (Sun and Crossland 2000). Neurons expressing GABA in the chick retina appear at E6 and, at this period, GABA is mainly synthesized from putrescine (de Mello et al. 1976, Hokoç et al. 1990). The classical enzyme that synthesizes GABA from glutamate (glutamic decarboxylase, GAD) first appears only at E11 (Hokoç et al. 1990). After this stage, GABA is mainly synthesized by the classical pathway involving GAD.

As observed in several regions of the CNS (BenAri 2002 for review), retinal GABA, acting on ionotropic receptors, also seems to be a depolarizing mediator at the beginning of the development (Yamashita and Fukuda 1993, Catsicas and Mobbs 2001). At E3, GABA is able to induce calcium influx by its depolarizing action (Yamashita and Fukuda 1993). Depolarization by GABA reaches a peak at E8 and undergoes a slight decrease around E12 (Catsicas and Mobbs 2001). Finally, at E14, GABA no more induces calcium influx and probably assumes its classical inhibitory function (Catsicas and Mobbs 2001).

Concerning to the neurogenesis pattern, the profile of GABAergic amacrine and horizontal cells showed a very slow proliferation rate up to E6, when only $20 \%$ of GAD-positive cells were considered generated. Then, between E6 and E9, 80\% of GAD expressing neurons are born (da Costa Calaza et al. 2000) (Fig. 5). Birth dates of GABAergic neurons were also determined in the rat retina by using BrdU or thymidine as markers (Lee et al. 1999, Silveira et al. 2007). In both cases, the rate of GABAergic cell generation peaked at E18 in both central and peripheral sectors of the retina, and displayed a homogenous generation rate from E14 to PN4, ending after that.

The early appearance of GABA during the retinal development raises the possibility that it could act as a factor modulating embryonic events, similar to other several neurotrophic factors (NGF, BDNF, NT3, etc) and molecules such as acetylcholine (Lipton et al. 1988), acetylcholinesterase (Blasina et al. 2000, Dupree and Bigbee 1996) and dopamine (Lankford et al. 1987, 1988, Reis et al. 2007). It has been shown that GABA expression occurs exactly at E6 (Hokoç et al. 1990) when most of GAD-IR cells starts to leave the cell cycle (da 
Costa Calaza et al. 2000), and long before GAD expression (Hokoç et al. 1990). Considering GABA as a neurotrophic molecule and knowing its inhibitory effect on DNA synthesis (LoTurco et al. 1995), GABA could carry specific signals that are need to arrest the mitotic cycle of GAD immunoreactive cells. Therefore, it could constitute a factor acting to control the proliferation of its own population. However, one cannot rule out the possibility of other substances influencing this process, and this possibility remains to be confirmed.

During the development, GABA functions are apparently mediated by ionotropic GABA receptors. $\mathrm{GABA}_{\mathrm{A} \beta 2-3}$, an important subunit of these receptors, is expressed in amacrine cells and in cells in the GCL (Barros et al. 2003). At E9, $\mathrm{GABA}_{\mathrm{A} \beta 2-3}$ immunoreactivity was restricted to the inner plexiform layer, and the first cell bodies immunoreactive to $\mathrm{GABA}_{\mathrm{A} \beta 2-3}$ were seen at E14. Thereafter, the number of cell bodies and the intensity of $\mathrm{GABA}_{\mathrm{A} \beta 2-3}$ immunoreactivity increased until the adult pattern is established. Interestingly, $\mathrm{GABA}_{\mathrm{A} \beta 2-3}$ amacrine positive cells are born in the same pattern as GAD positive cells, late in the neurogenesis period of the overall amacrine cell population (E7-E9) (Fig. 5).

\section{CONCLUSION: NO REGULAR PLAN FOR BIRTH!}

One interesting point that could arise from the data discussed above is that the neurogenesis period of the total cell population of the retina is not necessarily the same for different neurochemical cell subpopulations. Thus, although the neurogenesis of the total population of amacrine cells in chick retina takes place mainly from E2 to E9 (Fujita and Horii 1963, Kahn 1974, Spence and Robson 1989), subpopulations of amacrine cells expressing different phenotypes, like dopaminergic amacrine cells for example, can have distinct periods of neurogenesis, i.e. from E3 to E7 (Gardino et al. 1993, 1996, da Costa Calaza et al. 2000). By studying the ontogenesis and the neurogenesis of different retinal cell subpopulations, with distinct phenotypes, one could think that, for some of them, such as for the GABAergic system, there is a temporal window during the development, during which specific signal(s), responsible for their decision to leave the cell cycle, must be given. For the GABAergic system, it appears that there are im- portant signals around E6, which determine the end of the proliferation period. We cannot exclude the collaboration of progenitor cells competent to respond to some signal, which is present before E6 at their retinal microenvironment. However, for a full comprehension of the signals that modulate the neurogenesis of each specific neurochemical system, further experiments must be done. If there is not a common plan for the birth of the overall population of retinal cell, we can conclude that, among the great diversity of neurochemical cell types in the retina, there may be several genetic or epigenetic signals, factors, molecules, or even a combination of these, which are responsible not only for phenotype definition, but also for the establishment of the end of the mitotic cycle for each neurochemical cell type. The identification of signals and the determination of the proliferation periods of each cell type of the retina could be important for future therapeutic interventions using stem cells.

\section{ACKNOWLEDGMENTS}

This work was supported by funds from Conselho Nacional de Desenvolvimento Científico e Tecnológico (CNPq), Institutos Nacionais de Ciência e Tecnologia/ $\mathrm{CNPq}$ / Instituto Nacional de Neurociência Translacional, Fundação Carlos Chagas Filho de Amparo à Pesquisa do Estado do Rio de Janeiro (FAPERJ) and Programa de Apoio a Núcleos de Excelência (PRONEX), Pro-reitoria de Pesquisa, Pós-Graduação e Inovação (PROPPi)/UFF. We thank Prof. Fernando G. de Mello for the scientific reviews and Prof. Maria Christina F. de Mello for the manuscript revision. We also thank Prof. B. Schlosshauer for gently providing the mouse monoclonal antibody 2M6.

\section{RESUMO}

O embrião de galinha é um dos mais tradicionais modelos de estudos da neurociência do desenvolvimento e seu sistema visual tem sido um dos mais exaustivamente estudado. A retina tem sido utilizada como modelo para estudar o desenvolvimento do sistema nervoso. Aqui, nós descrevemos as características morfológicas que caracterizam cada estádio da retina em desenvolvimento e os estudos do período de neurogênese de algumas subpopulações de células neuroquímicamente específicas da retina usando uma combinação de imuno- 
histoquímica e autoradiografia de timidina-tritiada. Concluise que o período de proliferação das células dopaminérgicas, GABAérgicas, colinoceptivas e GABAceptivas não segue uma regra comum. Além disso, alguns grupos celulares neuroquimicamente distintos podem ter um período de proliferação mais restrito quando comparado ao da população total destas células.

Palavras-chave: desenvolvimento, neurogênese, sistemas neurotransmissores, ontogênese, proliferação.

\section{REFERENCES}

ARAKi M, IDE C AND SAITO T. 1982. Ultrastructural localization of acetylcholinesterase activity in the developing chick retina. Acta Histochem Cytochem 15: 242-255.

ARAKI M, FUKAdA Y, SHICHIDA Y AND Yoshizawa T. 1990. Localization of iodopsin in the chick retina during in vivo and in vitro cone differentiation. Invest Ophthalmol Visual Sci 31: 1466-1473.

BARnstable CJ. 1993. Glutamate and GABA in retinal circuitry. Curr Opin Neurobiol 3: 520-525.

Barros PH, CAlaza K dA C ANd Gardino PF. 2003. GABA (A $\beta 2-3$ ) immunoreactive cells in the developing chick retina. Int J Dev Neurosci 21: 35-40.

BEN-ARI Y. 2002. Excitatory actions of GABA during development: the nature of the nurture. Nat Neurosci 3: 728-739.

Blasina MF, Faria AC, Gardino PF, Hokoc JN, DE Mello FG and Dajas F. 2000. Evidence for a noncholinergic function of acetylcholinesterase during development of chicken retina as shown by fasciculin and other enzyme inhibitors. J Cell Tissue Res 299: 173-184.

Borba JC, HENZE IP, Silveira MS, Kubrusly RC, Gardino PF, DE MELlo MC, HoKoç JN AND DE MELLO FG. 2005. Pituitary adenylate cyclase-activating polypeptide (PACAP) can act as determinant of the tyrosine hydroxylase phenotype of dopaminergic cells during retina development. Brain Res Dev Brain Res 156: 193-201.

BRUHN S AND CEPKO CL. 1996. Development of the pattern of photoreceptors in the chick retina. J Neurosci 16: $1430-1439$.

CAtsicas M ANd MoBbs P. 2001. GABAB receptors regulate chick retinal calcium waves. J Neurosci 21: 897-910

CEPKO CL. 1996. The patterning and onset of opsin expression in vertebrate retinae Curr Opin Neurobiol 6: 542-546.

Chavarría T, Valenciano AI, Mayordomo R, Egea J, Comella JX, HallböÖK F, DE Pablo F AND DE
LA Rosa EJ. 2007. Differential, age-dependent MEKERK and PI3K-Akt activation by insulin acting as a survival factor during embryonic retinal development. Dev Neurobiol 67: 1777-1788.

Cook B, Portera-Cailliau C and Adler R. 1998. Developmental neuronal death is not a universal phenomenon among cell types in the chick embryo retina. J Comp Neurol 396: 12-19.

Coulombre AJ. 1955. Correlations of structural and biochemical changes in the developing retina of the chick. Am J Anat 96: 153-189.

Coulombre JL And Coulombre AJ. 1965. Regeneration of neural retina from the pigmented epithelium in the chick embryo. Dev Biol 12: 79-92.

Da Costa Calaza K, HoKoç JN and Gardino PF. 2000. Neurogenesis of GABAergic cells in the chick retina. Int J Devl Neuroscience 18: 721-726.

de Carvalho RP, BraAs KM, Adler R and SNyder SH. 1992. Developmental regulation of adenosine A1 receptors, uptake sites and endogenous adenosine in the chick retina. Brain Res Dev Brain Res 70: 87-95.

de Mello FG, Bachrach U and Nirenberg M. 1976. Ornithine and glutamic acid decarboxylase activities in the developing chick retina. J Neurochem 27: 847-851.

DeLong GR And Coulombre AJ. 1965. Development of the retinotectal topographic projection in the chick embryo. Exp Neurol 13: 351-363.

DupreE JL And BigBeE JW. 1996. Acetylcholinesterase inhibitor treatment delays recovery from axotomy in cultured dorsal root ganglion neurons. J Neurocytol 25: 439-454.

EDQVIST PH AND HALLBÖÖK F. 2004. Newborn horizontal cells migrate bi-directionally across the neuroepithelium during retinal development. Development 131: 13431351.

EHINGER B. 1978. Biogenic Monoamines and aminoacids as retinal neurotransmitters. In: COOL SJ AND SMITH EL (Eds), Frontiers in Visual Science. Berlin-HeidelbergNew York Springer-Verlag, p. 42-53.

EHRLICH D. 1981. Regional specialization of the chick retina as revealed by the size and density of neurons in the ganglion cell layer. J Comp Neurol 195: 643-657.

EHRLICH D AND Morgan IG. 1980. Kainic acid destroys displaced amacrine cells in posthatch chicken retina. Neurosci Lett 17: 43-48.

EVANS JA AND BATTELLE BA. 1987 Histogenesis of dopaminergic-containing neurons in the rat retina. Exp Eye Res 44: 407-414. 
FARAH MH. 2004. Cumulative labeling of embryonic mouse neural retina with bromodeoxyuridine supplied by an osmotic minipump. J Neurosci Meth 134: 169-178.

Fekete DM, Perez-Miguelsanz J, Ryder EF AND CEPKO CL. 1994. Clonal analysis in the chicken retina reveals tangential dispersion of clonally related cells. Dev Biol 166: 666-682.

FISCHER AJ, MCKINNON LA, NATHANSON NM AND STELL WK. 1998a. Identification and localization of muscarinic acetylcholine receptors in the ocular tissues of the chick. J Comp Neurol 392: 273-84.

Fischer AJ, Seltner RL, Poon J And Stell WK. 1998b. Immunocytochemical characterization of quisqualic acid- and N-methyl-D-aspartate-induced excitotoxicity in the retina of chicks. J Comp Neurol 393: 1-15.

Fischer AJ, Wallman J, Mertz JR and Stell WK. 1999. Localization of retinoid binding proteins, retinoid receptors, and retinaldehyde dehydrogenase in the chick eye. J Neurocytol 28: 597-609.

Fischer AJ, OMAR G, WALton NA, Verrill TA AND UNSON CG. 2005. Glucagon-expressing neurons within the retina regulate the proliferation of neural progenitors in the circumferential marginal zone of the avian eye. $\mathrm{J}$ Neurosci 25: 10157-10166.

Fischer AJ, SKorupa D, SChONBERG DL AND WALton NA. 2006. Characterization of glucagon-expressing neurons in the chicken retina. J Comp Neurol 496: 479-494.

Fischer AJ, Stanke JJ, Aloisio G, Hoy H And Stell WK. 2007. Heterogeneity of horizontal cells in the chicken retina. J Comp Neurol 500: 1154-1171.

FUJitA S AND HoriI M. 1963. Analysis of cytogenesis in chick retina by tritiated thymidine autoradiography. Arch histol Jpn 23: 359-366.

FUKUDA M ET AL. 1981. Localization of vasoactive intestinal polypeptide and neurotensin immunoreactivities in the avian retina. Curr Eye Res 1: 115-118.

GARdino PF, Dos SAntos RM And HoKoç JN. 1993. Histogenesis and topographical distribution of tyrosine hydroxylase immunoreactive amacrine cells in the developing chick retina. Dev Brain Res 72: 226-236.

Gardino PF, Calaza KC, Hamassaki-Britto DE, Lindstrom JM, BRITTO LR AND HoKoÇ JN. 1996. Neurogenesis of cholinoceptive neurons in the chick retina. Brain Res Dev Brain Res 95: 205-212.

Ge S, Pradhan DA, Ming GL and Song H. 2007. GABA sets the tempo for activity-dependent adult neurogenesis. Trends Neurosci 30: 1-8.
Génis-Gálvez JM, Pulelles L and Prada C. 1977. Inverted displaced retinal amacrine cells and their embryonic development in the chick retina. Exp Neurol 56: 151-157.

GÉnis-Gálvez JM, Garcia-Lomas V, Prada FA AND ARMENGOL JA. 1981. Developmental study of axon formation in the horizontal neurons of the retina of the chick embryo. Anat Embryol 161: 305-317.

Guimarães MZ, Hokoç JN, Duvoisin R, Reis RA AND De Mello FG. 2001. Dopaminergic retinal cell differentiation in culture modulation by forskolin and dopamine. Eur J Neurosci 13: 1931-1937.

HAMASSAKI-BRITTO DE, GARDino PF, HOKOÇ JN, KEYSER KT, KARTEN HJ, LindSTROM JM AND BRITTO LR. 1994. Differential development of alpha-bungarotoxin-sensitive and alpha-bungarotoxin-insensitive nicotinic acetylcholine receptors in the chick retina. J Comp Neurol 347: 161-170.

Hamburger V and Hamilton HL. 1951. A series of normal stages in the development of the chick embryo. $J$ Morphol 88: 49-92.

Hanawa J, TaKahashi K and KaWAmoto N. 1976. A correlation of embryogenesis of visual cells and early receptor potential in the developing retina. Exp Eye Res 23: 587-594.

HERING H AND KRÖGER S. 1996. Formation of synaptic specializations in the inner plexiform layer of the developing chick retina. J Comp Neurol 375: 393-405.

Hokoç JN, Ventura ALM, Gardino PF AND DE MELlo FG. 1990. Developmental immunoreactivity for GABA and GAD in the avian retina: possible alternative pathway for GABA synthesis. Brain Res 532: 197-202.

Hughes WF AND LaVelle A. 1974. On the synaptogenic sequence in the chick retina. Anat Rec 179: 297-302.

Hyer JT, Mima T AND Mikawa T. 1998. FGF1 patterns the optic vesicle by directing the placement of the neural retina domain. Development 125: 869-877.

KAHN AJ. 1973. Ganglion cell formation in the chick neural retina. Brain Res 63: 285-290.

KAHN AJ. 1974. An autoradiographic analysis of the time of appearance of neurons in the developing chick neural retina. Dev Biol 38: 30-40.

Kalloniatis M AND Fletcher EL. 1993. Immunocytochemical localization of the amino acid neurotransmitters in the chicken retina. J Comp Neurol 336: 174-193.

Kiyama H, Katayama-Kumoi Y, Kimmel J, SteinBusch H, Powell JF, SMith AD AND TOHYAma M. 
1985. Three dimensional analysis of retinal neuropeptides and amine in the chick. Brain Res Bull 15: 155-165.

LANKFord KL, De Mello FG and Klein WL. 1987. A transient embryonic dopamine receptor inhibits growth cone motility and neurite outgrowth in a subset of avian retina neurons. Neurosci Lett 75: 169-174.

Lankford KL, De Mello FG and Klein WL. 1988. D1-type dopamine receptors inhibit growth cone motility in cultured retina neuronsevidence that neurotransmitters act as morphogenic growth regulators in the developing central nervous system. Proc Nat Acad Sci USA 85: 2839-2843.

Large TH, Rauh JJ, De Mello FG and Klein WL. 1985. Two molecular weight forms of muscarinic acetylcholine receptors in the avian central nervous systemswitch in predominant form during differentiation of synapses. Proc Natl Acad Sci USA 82: 8785-8789.

LAVAIL JH AND COWAN WM. 1971. The development of the chick optic tectum. I. Normal morphology and cytoarchitectonic development. Brain Res 28: 391-419.

LeE MY, Shin SL, Han SH And Chun MH. 1999. The birth dates of GABA immunorreactive amacrine cells in rat retina. Exp Brain Res 128: 309-314.

Lipton SA, Frosch MP, Phillips MD, TAUCK DL AND AIZENMAN E. 1988. Nicotinic antagonists enhance process outgrowth by rat retinal ganglion cells in culture. Science 239: 1293-1296.

LoTurco JJ, OWEns DF, HeAth MJS, DaVies MBE AND KRIEGSTEIN AR. 1995. GABA and glutamate depolarize cortical progenitor cells and inhibit DNA synthesis. Neuron 15: 1287-1298.

Loureiro-dos-Santos NE, Reis RA, Kubrusly RC, DE Almeida OM, Gardino PF, De Mello MC AND DE MELLO FG. 2001. Inhibition of choline acetyltransferase by excitatory amino acids as a possible mechanism for cholinergic dysfunction in the central nervous system. J Neurochem 77: 1136-1144.

Loureiro-dos-Santos NE, Prado MA, Reis RA, Gardino PF, de Mello MC and de Mello FG. 2002. Regulation of vesicular acetylcholine transporter by the activation of excitatory amino acid receptors in the avian retina. Cell Mol Neurobiol 22: 727-740.

LujÁN R, Shigemoto R AND LÓPEZ-BENDito G. 2005. Glutamate and GABA receptor signalling in the developing brain. Neuroscience 130: 567-580.

MARQUARDT T AND GRUSS P. 2002. Generating neuronal diversity in the retina one for nearly all. Trends Neurosci 25: $32-38$.
Martins RA AND PeARson RA. 2008. Control of cell proliferation by neurotransmitters in the developing vertebrate retina. Brain Res 1192: 37-60.

MASLAND RH. 2001. Neuronal diversity in the retina. Curr Opin Neurobiol 11: 431-436.

Masland RH. 2004. Neuronal cell types. Curr Biol 14: R497-500.

MASSEy SC AND RedBuRn D. 1987. Transmitter circuits in the vertebrate retina. Prog Neurobiol 28: 55-96.

Meller K AND Tetzlaff W. 1976. Scanning electron microscopic studies on the development of the chick retina. Cell Tissue Res 170: 145-159.

MeY J AND Thanos S. 2000. Development of the visual system of the chick. I. Cell differentiation and histogenesis. Brain Res Brain Res Rev 32: 343-379.

Millar T, Ishimoto I, Johnson CD, Epstein ML, Chubb IW and Morgan IG. 1985. Cholinergic and acetylcholinesterase-containing neurons of the chicken retina. Neurosci Lett 61: 311-316.

Mitrofanis J, Vigny A And Stone J. 1988. Distribution of cathecolaminergic cells in the retina of rat, guinea-pig, cat and rabbitindependence of ganglion cell distribution. J Comp Neurol 26: 71-14.

Mosinger JL, YAzUlla S And Studholme KM. 1986. GABA-like immunoreactivity in the vertebrate retina species comparison. Exp Eye Res 42: 631-644.

Okano T, KoJima D, Fukada Y, Shichida Y And Yoshizawa T. 1992. Primary structures of chicken cone visual pigments: vertebrate rhodopsins have evolved out of cone visual pigments. Proc Nat Acad Sci USA 89: 5932-5936.

OLSON MD. 1979. Scanning electron microscopy of developing photoreceptors in the chick retina. Anat Rec 193: 432-438.

OPPENHEIM RW. 1968. Light responsivity in chick and duck embryos just prior to hatching. Anim Behav 16: 276-280.

Paes de Carvalho R And De Mello FG. 1982. Adenosine-elicited accumulation of adenosine $3^{\prime}, 5^{\prime}$-cyclic monophosphate in the chick embryo retina. J Neurochem 38: 493-500.

Pearson R, Catsicas M, Becker D and Mobbs P. 2002. Purinergic and muscarinic modulation of the cell cycle and calcium signaling in the chick retinal ventricular zone. J Neurosci 22: 7569-7579.

Prada C, Puelles L, GÉnis-Gálvez JM and Ramírez G. 1987. Two modes of free migration of amacrine cell neuroblasts in the chick retina. Anat Embryol (Berl) 175: 281-287. 
Prada C, Puga J, Pérez-Méndez L, López R And RAMÍREZ G. 1991. Spatial and temporal patterns of neurogenesis in the chick retina. Eur J Neurosci 3: 559-569.

Prado MA, Reis RA, Prado VF, de Mello MC, Gomez MV AND DE MEllo FG. 2002. Regulation of acetylcholine synthesis and storage. Neurochem Int 41: 291-299.

RAGER G. 1976. Morphogenesis and physiogenesis of the retino-tectal connection in the chicken. II. The retinotectal synapses. Proc R Soc Lond B Biol Sci 192: 353370.

RAGER G AND RAGER U. 1978. Systems-matching by degeneration. I. A quantitative electron microscopic study of the generation and degeneration of retinal ganglion cells in the chicken. Exp Brain Res 33: 65-78.

RAger U, RAger G AND Frei B. 1993. Central retinal area is not the site where ganglion cells are generated first. J Comp Neurol 334: 529-544.

Reis RA, Ventura Al, Kubrusly RC, de Mello MC AND DE MELlo FG. 2007. Dopaminergic signaling in the developing retina. Brain Res Rev 54: 181-188.

RoBINSON SR. 1988. Cell death in the inner and outer nuclear layers of the developing cat retina. J Comp Neurol 267: 507-515.

Schlosshauer B, Grauer D, Dtting D and VanseLOW J. 1991. Expression of a novel Muller glia specific antigen during development and after optic nerve lesion. Development 111: 789-799.

Sernagor E, Young C And Eglen SJ. 2003. Developmental modulation of retinal wave dynamics shedding light on the GABA saga. J Neurosci 23: 7621-7629.

Shen SC, GREenfield P AND Boell EJ. 1956. Localization of acetylcholinesterase in chick retina during histogenesis. J Comp Neurol 106: 433-461.

SILVEIRA ACD, GARDino PF, BEVILAQUA MCN AND HoKOÇ JN. 2007. Neurogenesis of GABAergic cells in the retina of malnourished rats. Int J Dev Neurosci 25: 325-333.

SPENCE SG AND RoBSOn JA. 1989. An autoradiographic analysis of neurogenesis in the chick retina in vitro and in vivo. Neuroscience 32: 801-812.

SPIRA AW, Millar TJ, IShimoto I, EPSTEIN ML, JOHNSON CD, DAHL JL AND MORGAN IG. 1987. Localization of choline acetyltransferase like immunoreactivity in the embryonic chick retina. J Comp Neurol 260: 526-538.
SUN H AND CROSSLAND WJ. 2000. Quantitative assessment of localization and colocalization of glutamate, aspartate, glycine and GABA immunoreactivity in the chick retina. Anat Rec 260: 158-179.

Syed MM, LeE S, He S ANd Zhou ZJ. 2004. Spontaneous waves in the ventricular zone of developing mammalian retina. J Neurophysiol 91: 1999-2009.

TACHIBANA M AND KANEKO A. 1988. Retinal bipolar cells receive negative feedback input from GABAergic amacrine cells. Vis Neurosci 12: 297-305.

ThORESON WB AND WitKovsky P. 1999. Glutamate receptors and circuits in the vertebrate retina. Prog Ret Eye Res 18: 765-810.

Tung NN, Morgan IG And Ehrlich D. 1990. A quantitative analysis of the effects of excitatory neurotoxins on retinal ganglion cells in the chick. Vis Neurosci 4: 217223.

Ventura ALM, Klein WL and De Mello FG. 1984. Differential ontogenesis of D1 and D2 dopaminergic receptors in the chick embryo retina. Dev Brain Res 12: $217-223$

Vogel Z AND NiRENBERG M. 1976. Localization of acetylcholine receptors during synaptogenesis in retina. Proc Natl Acad Sci USA 73: 1806-1810.

WONG WT AND WONG RO. 2001. Changing specificity of neurotransmitter regulation of rapid dendritic remodeling during synaptogenesis. Nature Neurosci 4: 351-352.

Wong WT, SAnes JR And Wong RO. 1998. Developmentally regulated spontaneous activity in the embryonic chick retina. J Neurosci 18: 8839-8852.

WU DK AND CEPKO CL. 1993. Development of dopaminergic neurons is insensitive to optic nerve section in the neonatal rat retina. Brain Res Dev Brain Res 742: 53-60.

YAMASHITA M AND FUKUDA Y. 1993. Calcium channels and GABA receptors in the early embryonic chick retina. J Neurobiol 24: 1600-1614.

YAZULLA S. 1986. GABAergic mechanisms in the retina. Prog Retinal Res 5: 1-12. 